\title{
TINJAUAN AMBANG BATAS PEROLEHAN SUARA BERDASARKAN UNDANG- UNDANG NOMOR 8 TAHUN 2012 TENTANG PEMILIHAN ANGGOTA DEWAN PERWAKILAN RAKYAT, DEWAN PERWAKILAN DAERAH DAN DEWAN PERWAKILAN RAKYAT DAERAH TERHADAP UNDANG-UNDANG DASAR 1945
}

(A Legal Analysis on Electoral Threshold in Law Number 8 Year 2012 On The Election for Members of House of Representative, House of Regional Representative and Local House of Representative against the Republic of Indonesian 1945 Constitution)

\author{
Yogo Pamungkas \\ Fakultas Hukum Universitas Trisakti Jakarta \\ Jalan Kyai Tapa Grogol Jakarta Barat \\ Email: pamungkasyogo@gmail.com
}

Naskah diterima: 21 Februari 2014; revisi: 11 April 2014; disetujui: 29 April 2014

\begin{abstract}
Abstrak
Ambang batas perolehan suara adalah usaha memperoleh hasil pemilihan umum yang berkualitas dengan pengisian kursi di parlemen dan juga untuk menghasilkan pengelolaan pemerintah yang stabil. Namun cara ini selalu terbentur atau dibenturkan dengan persoalan demokrasi, disproporsionalitas pemilihan umum dan persoalan aspirasi rakyat. Permasalahan yang diajukan dalam tulisan ini adalah apakah putusan Mahkamah Konstitusi atas permohonan uji materi tentang Ambang batas perolehan suara pemilu 2014 sudah tepat dan bagaimana penerapan yang tepat atas ambang batas perolehan suara pada pemilu 2014? Untuk menganalisis masalah ini menggunakan tipe penelitian normatif dengan data sekunder yang dianalisis dengan pendekatan kualitatif dan deduktif. Hasil penelitian ini menunjukkan bahwa penetapan ambang batas perolehan suara ditentukan sebesar 3.5\% suara nasional hanya berlaku di jenjang nasional saja. Penetapan ambang batas perolehan suara tidak bertentangan dengan Undang-Undang Dasar 1945. Penerapan atas ambang batas perolehan suara ini juga tidak tepat karena hanya diterapkan pada tataran nasional saja, karena sebaiknya penerapan ambang batas perolehan suara diterapkan di setiap jenjang.

Kata Kunci: Ambang Batas Perolehan Suara, Pemilihan Umum, Partai Politik
\end{abstract}

\begin{abstract}
Basically, Electoral threshold is the effort to achieve high quality election result by choosing representative person to represent political party. Besides, in order to achieve secure governance management. Unfortunately electoral threshold is often opposed with the issues of democracy, proportional principles of election and people's aspiration. There are questions in this research: is the verdict of constitutional court about parliamentary threshold has been right? How the application of parliamentary threshold in the election 2014? This research use normative research method with secondary data. This research finds that: first, Electoral threshold is 3.5\% of total national votes and it is only enforce within national scope; second, electoral threshold is in accordance within the Republic of Indonesia's 1945 constitution; third. It is not ideal to enforce electoral threshold only within national scope instead of local scope. Therefore, it is suggested that Electoral threshold must be enforce within both national and local scopes.
\end{abstract}

Keywords: Electoral Threshold, Election, Political Party 


\section{A. Pendahuluan}

Banyak negara-negara yang menyatakan bahwa negaranya adalah negara yang demokratis dengan berbagai terminologi yang didefinisikan sendiri dan bahkan beberapa negara yang jelas-jelas tidak menerapkan asas demokrasi pun masih tetap berusaha membuat sistem yang seolah-olah demokratis.

Ciri dasar dari sebuah negara yang menerapkan demokrasi adalah hidupnya partai politik dan berlangsungnya pemilihan umum secara periodik. Negara-negara yang menerapkan demokrasi biasa memiliki lebih dari dua partai baik yang bersistem dwi partai maupun multi partai. Sementara bagai negara yang otoriter meski mempunyai partai politik biasanya hanya ada satu partai milik pemerintah.

Menurut Samuel Huntington, pelembagaan partai adalah proses pemantapan partai politik baik dalam wujud perilaku yang mempola maupun dalam sikap maupun budaya ${ }^{1}$. Huntington menegaskan bahwa dalam konteks pembangunan politik, yang terpenting bukan jumlah partai yang ada, melainkan sejauh mana kekokohan dan kemudahan beradaptasi sistem kepartaian yang berlangsung. Sistem kepartaian dapat dikatakan kokoh dan mudah beradaptasi apabila mampu menyerap dan menyatukan semua kekuatan sosial baru yang muncul sebagai akibat modernisasi. Dari sudut pandang ini jumlah partai hanya akan menjadi penting jika ia mempengaruhi kapasitas sistem untuk membentuk saluran-saluran kelembagaan yang diperlukan guna menampung partisipasi politik. $^{2}$

Sistem pemilu menurut Arend Lijphart diartikan sebagai satu kumpulan metode atau cara warga masyarakat memilih para wakil mereka. ${ }^{3}$ Dalam membahas tentang sistem pemilu sangat perlu diperhatikan apa yang dinamakan electoral formula atau formula pemilihan umum yang berarti sistem apa yang hendak digunakan. ${ }^{4}$ Secara umum terdapat dua kelompok sistem pemilu yaitu sistem representasi-proposional (Propotional Representative) dan sistem Pluratitas-Mayoritas (Plurality-Majority) atau disebut Sistem Distrik. ${ }^{5}$ Problematika umum sebuah negara yang menerapkan sistem multi partai adalah stabilitas politik yang lemah akibat banyaknya jumlah partai. Pemerintahan yang disokong oleh beberapa partai yang tidak mencapai perolehan dukungan mayoritas tunggal, sehingga pemerintahan sering dijalankan secara transaksional sehingga berdampak pada kerugian rakyat.

Oleh karena itu timbul pemikiran tentang sistem multi partai sederhana untuk memciptakan pengelolaan pemerintahan yang baik. Cara yang paling alami untuk menyederhanakan partai tersebut adalah dengan menentukan ambang batas perolehan suara.

Pemberlakuan ambang batas atau batas representasi perwakilan sangat dimungkinkan

Samuel Huntington dalam Lili Romli, "Reformasi Partai Politik dan Sistem Kepartaian di Indonesia," Jurnal Politica (2011):201

2 Ibid.

3 Arend Lijphart dalam Affan Gafar, Politik Indonesia Transisi Menuju Demokrasi (Yogyakarta: Pustaka Pelajar, 2000), hlm. 255.

4 Ibid.

5 Ibid. 
dalam pemilihan umum. Artinya akan ada tingkatan dukungan minimal yang diperlukan partai untuk memperoleh perwakilan. Penerapannya bisa secara legal (legal threshold) yaitu dicantumkan dalam undang-undang atau semata de facto secara matematis (efektif). ${ }^{6}$

Nohlen $^{7}$ berpendapat terdapat empat kriteria dalam menentukan ambang batas pertama, prosentase perolehan suara. Pertama, besaran prosentase perolehan suara yang paling umum adalah 3\% (Spanyol) hingga 5\% (Jerman), sementara prosentase yang terendah diterapkan di Belanda, yakni sebesar 0.5\% dan negara yang paling tinggi menerapkan, yakni Turki sebesar $10 \%$. Kedua, ambang batas berdasar lokasi penerapan yaitu penentuan ambang batas berdasar lokasi daerah pemilihan (Spanyol), atau diterapkan secara nasional (Jerman) atau di dua tingkat daerah pemilihan (daerah dan nasional) sebagaimana di Swedia. Ketiga, ambang batas didasarkan pada tahap awal sebelum penghitungan perolehan kursi atau berdasar tahap penghitungan kursi. Keempat, ambang batas dengan obyek partai atau koalisi partai.

Pelaksanaan pengurangan jumlah partai politik dengan menggunakan ambang batas perolehan suara secara positif akan mengurangi partai politik, namun pada sisi lain terdapat sekian suara terbuang dan tidak terwakili. Penambahan jumlah suara terbuang berakibat pada meningkatnya disproporsionalitas hasil pemilu. Hal ini juga membuat kualitas demokrasi menjadi menurun.

Data Komisi Pemilihan Umum ${ }^{8}$ menunjukkan, pada pemilihan umum tahun 1999 yang tidak menerapkan ambang batas, terdapat 3.755.383 atau $3,55 \%$ suara terbuang. Jika ambang batas diterapkan jumlah suara terbuang akan bertambah. Dengan besaran ambang batas 2,5\% maka jumlah suara terbuang melonjak lima kali lipat menjadi 14.195.221 atau 13,41\% namun jumlah suara terbuang tidak bertambah ketika ambang batas dinaikkan menjadi $3 \%$ atau $4 \%$ atau $5 \%$.

Di negara lain, penerapan ambang batas juga mengakibatkan suara terbuang. Turki sebagai negara yang menerapkan ambang batas paling tinggi yaitu $10 \%$, pada pemilihan umum 2002 terdapat suara terbuang sebesar $45 \%$, pada pemilihan umum tahun 1993 di Polandia dengan ambang batas $5 \%$ untuk partai politik dan $8 \%$ untuk koalisi terdapat $22 \%$ suara terbuang, sementara di Ukraina dengan ambang batas $3 \%$ pada pemilihan umum 2006 terdapat $22 \%$ suara terbuang sedang di Lithuania dengan ambang batas $5 \%$ pada pemilihan umum tahun 2000 terdapat $23 \%$ suara terbuang. ${ }^{9}$ Oleh karena itu diperlukan rumusan yang tepat tentang prosentase ambang batas yang pada satu sisi dapat secara signifikan mengurangi jumlah partai namun pada sisi lain tidak menambah disproporsionalitas suara sehingga kualitas demokrasi masih tetap dapat dipertahankan demokratisasi dalam pemilihan umum.

\footnotetext{
6 Harun Husein et.al., Politik Hukum Sistem Pemilu: Potret Keterbukaan dan Partisipasi Publik Dalam Penyusunan Undang-Undang Nomor 8 tahun 2012 tentang pemilihan umum anggota DPR, DPD dan DPRD (Jakarta: Perludem, 2013), hlm. 116.

Nohlen dalam Didik Supriyanto dan August Mellaz, Ambang Batas Perwakilan (Jakarta: Perludem, 2011), hlm. 19.

$8 \quad$ Ibid., hlm. 59.

9 Ibid.
} 
Undang-Undang yang mengatur tentang Pemerintahan daerah, pemerintahan Indonesia dibagi dua jenjang pemerintahan daerah yaitu provinsi sebagai pemerintah derah yang berada satu jenjang dari pemerintah pusat dan kabupaten atau kota yang merupakan jenjang pemerintah daerah di bawah provinsi. Oleh karena setiap jenjang tersebut memiliki Dewan Perwakilan Rakyat Daerah, maka dalam pemilihan umum selain memilih wakil rakyat di tingkat pusat (DPR) juga memilih wakil rakyat di tingkat daerah provinsi maupun kabupaten dan kota.

Oleh karena ada tiga jenjang dalam pemilihan umum ini maka penerapan ambang batas perolehan suara dapat dilakukan dengan dua cara yaitu, ambang batas perolehan suara hanya diberlakukan untuk DPR saja. Pendapat ini didukung Mahkamah Konstitusi dalam putusan Putusan Mahkamah Konstitusi Nomor 52/PUU-X.2012, yang menyatakan bahwa pemberlakuan ambang batas "secara nasional" adalah inkonstitusional. Dasar pemikiran Mahkamah Konstitusi pada poin 3.25, mengatakan bahwa, Pasal 208 UndangUndang Nomor 8 Tahun 2012 dan Penjelasannya bertujuan untuk penyederhanaan kepartaian secara alamiah, namun dari sudut substansi, ketentuan tersebut tidak mengakomodasi semangat persatuan dalam keberagaman. Ketentuan tersebut berpotensi menghalanghalangi aspirasi politik di tingkat daerah, padahal terdapat kemungkinan adanya partai politik yang tidak mencapai PT secara nasional sehingga tidak mendapatkan kursi di DPR, namun di daerahdaerah, baik di tingkat provinsi atau kabupaten/ kota, partai politik tersebut memperoleh suara signifikan yang mengakibatkan diperolehnya kursi di lembaga perwakilan masing-masing daerah tersebut. Bahkan secara ekstrim dimungkinkan adanya partai politik yang secara nasional tidak memenuhi PT 3,5\%, namun menang mutlak di daerah tertentu. Hal demikian akan menyebabkan calon anggota DPRD yang akhirnya duduk di DPRD bukanlah calon anggota DPRD yang seharusnya jika merunut pada perolehan suaranya, atau dengan kata lain, calon anggota DPRD yang akhirnya menjadi anggota DPRD tersebut tidak merepresentasikan suara pemilih di daerahnya. Politik hukum sebagaimana yang ditentukan dalam Pasal 208 Undang-Undang Nomor 8 Tahun 2012 dan Penjelasannya tersebut justru bertentangandengan kebhinekaan dan kekhasan aspirasi politik yang beragam di setiap daerah. Sementara pada poin 3.25.1, menyatakan bahwa pemberlakuan ambang batas perolehan suara secara nasional yang mempunyai akibat pada hilangnya kursi-kursi partai politik yang tidak memiliki kursi di DPR namun partai politik bersangkutan memenuhi ketentuan bilangan pembagi pemilih di daerah dan menjadikan kursi-kursi tersebut dimiliki partai politik lain yang sebenarnya tidak memenuhi bilangan pembagi pemilih namun memiliki kursi di DPR, justru bertentangan dengan kedaulatan rakyat, hak politik, dan rasionalitas, sehingga bertentangan pula dengan tujuan pemilihan umum itu sendiri yaitu untuk memilih wakil rakyat mulai dari tingkat pusat hingga daerah.

Putusan Mahkamah Konstitusi nomor 52/ PUU-X/2012 menyatakan kebijakan terkait pemberlakuan PT secara nasional diharapkan dapat menciptakan sinergitas program yang dijalankan pemerintah pusat dan daerah. Fakta yang terjadi sebelumnya sering kali program yang dicanangkan pemerintah pusat tidak sejalan dengan kebijakan yang ada di daerah. Hal ini disebabkan masing-masing keterwakilan partai politik di DPR dan DPRD berbeda latar 
belakangnya dikarenakan dalam pemilu Tahun 2009, partai politik yang terwakili di DPR belum tentu mempunyai keterwakilan di DPRD, begitu juga sebaliknya. Hal ini sangat mempengaruhi sinergitas program pembangunan di pusat dan daerah, sehingga penyelenggaraan Pemerintah kurang efektif.

\section{B. Permasalahan}

Berdasarkan uraian tersebut di atas, menimbulkan dua masalah krusial yaitu apakah putusan Mahkamah Konstitusi yang menentukan ambang batas perolehan suara pada pemilu berdasar Undang-Undang Nomor 8 tahun 2012 hanya ada pada jenjang nasional saja sudah tepat? Masalah kedua adalah bagaimana penerapan ambang batas perolehan suara sehingga memenuhi aspirasi masyarakat sekaligus dapat menjadi cara untuk menyederhanakan jumlah partai politik?

\section{Metode Penelitian}

Kajian ini mengambil obyek UndangUndang Nomor 8 Tahun 2012 dan putusan Mahkamah Konstitusi sehingga pola kajian yang dilakukan adalah yuridis normatif dengan melakukan pendekatan berupa kajian tentang kesesuaian ketentuan ambang batas perolehan suara pemilihan umum yang diatur dalam Undang-Undang Nomor 8 tahun 2012 tentang pemilihan umum Anggota DPR, DPRD dan DPD dengan Undang-Undang Dasar 1945 dengan seluruh data pendukung didapat melalui studi kepustakaan yang dianalisis secara kualitatif dengan mengurai secara deskriptif dan preskriptif.

\section{Pembahasan}

International IDEA menjelaskan bahwa ambang batas adalah jumlah minimal yang harus diperoleh partai politik untuk mendapatkan perwakilan. Ambang batas dapat dikategorikan menjadi dua yaitu ambang batas natural atau efektif, biasanya tercantum dalam undangundang dan ambang batastersembunyi (hidden), karena salah satu yang termasuk ambang batas tersembunyi adalah ukuran daerah pemilihan, karena keberlakuannya juga mempengaruhi jumlah partai politik yang mendapatkan kursi di parlemen. ${ }^{10}$

Penggunaan metode konversi suara hasil pemilihan umum ke perolehan kursi, setidaknya terdapat tiga metode yaitu Kuota murni, kuota drop, divisor Webster, d' hondt. Kuota murni atau metode kuota Hamilton/Hare/Niemayer, atau disebut juga metode kuota-LR (largest remainders), atau sisa terbanyak adalah metode konversi suara ke kursi, yakni setelah ditetapkan angka BPP, ditetapkan perolehan jumlah kursi tiap Partai Politik Peserta Pemilu di suatu daerah pemilihan, dengan ketentuan: ${ }^{11}$

a. Apabila jumlah suara sah suatu Partai Politik Peserta Pemilu sama dengan atau lebih besar dari BPP, maka dalam penghitungan tahap pertama diperoleh sejumlah kursi dengan kemungkinan terdapat sisa suara yang akan dihitung dalam penghitungan tahap kedua;

b. Apabila jumlah suara sah suatu Partai Politik Peserta Pemilu lebih kecil dari pada BPP,

10 Harun Husein, Op.Cit., hlm. 141.

11 Undang-Undang Nomor 8 tahun 2012 tentang Pemilihan Umum Anggota Dewan Perwakilan Rakyat, Dewan Perwakilan Daerah, Dan Dewan Perwakilan Rakyat Daerah. 
maka dalam penghitungan tahap pertama tidak diperoleh kursi, dan jumlah suara sah tersebut dikategorikan sebagai sisa suara yang akan dihitung dalam penghitungan tahap kedua dalam hal masih terdapat sisa kursi di daerah pemilihan yang bersangkutan;

c. Penghitungan perolehan kursi tahap kedua dilakukan apabila masih terdapat sisa kursi yang belum terbagi dalam penghitungan tahap pertama, dengan cara membagikan jumlah sisa kursi yang belum terbagi kepada Partai Politik Peserta Pemilu satu demi satu berturut-turut sampai habis, dimulai dari Partai Politik Peserta Pemilu yang mempunyai sisa suara terbanyak.

Kedua, metode kuota Drop. Metode ini merupakan respon atas kritik, bahwa metode kuota murni cenderung merugikan partai politik peraih suara besar dan menguntungkan partai politik peraih suara menengah pada masing-masing daerah pemilihan. Ilustrasinya ini seperti ini: jika kuota suara satu kursi sama dengan 1.000, partai yang memiliki 1.500 suara, sama-sama mendapatkan 1 kursi dengan partai politik yang memiliki 600 suara. Oleh karena itu agar partai peraih suara besar tidak dirugikan maka penentuan kuota suara 1 kursi, bukan lagi total suara dibagi jumlah kursi, melainkan total suara dibagi dengan jumlah kursi +1 atau dalam bentuk rumus menjadi $q=S / V+1$. Selanjutnya cara menghitungnya sama dengan metode kuota murni, yaitu tahap pertama menentukan partai politik yang mendapatkan kursi utuh, dan tahap kedua menentukan partai politik yang mendaptkan sisa kursi yang belum terbagi. ${ }^{12}$

Ketiga, metode divisor d'Hondt/Jefferson sesungguhnya merupakan respons lain atas metode kuota murni, yang dianggap merugikan partai politik peraih suara besar di setiap daerah pemilihan. Cara menghitung perolehan kursi ke partai politik metode ini adalah membagi perolehan suara setiap partai politik dengan bilangan pembagi 1, 2, 3, 4, dst. Selanjutnya hasil pembagian suara setiap partai politik itu diranking, dan angka tertinggi secara berturutturut mendapatkan kursi pertama, kursi kedua, kursi ketiga dst, sesuai dengan jumlah kursi yang tersedia. ${ }^{13}$

Keempat, metode divisor St Lague/Webster. Metode ini merupakan kritik terhadap metode kuota Drop dan divisor d'Hondt/Jeferson, yang terlalu menguntungkan partai politik peraih suara besar, dan merugikan partai politik peraih suara menengah dan kecil. Kedua metode itu sering menyalahi prinsip proporsionalitas matematika ini: partai politik yang memiliki kuota 0,4 sampai dengan 1,4 hanya mendapatkan 1 kursi; atau, pertai yang memiliki kuota 0,4 seharusnya tidak dapat kursi; partai politik yang memilki kuota 1,4 seharusnya tidak mendapatkan lebih dari 1 kursi. Metode ini tetap menggunakan bilangan pembagi, hanya tidak 1 , 2, 3, 4, dst melainkan 1, 3, 5, 7 dst atau bilangan ganjil. Adapun cara menghitungnya tetap sama dengan metode divisor d'Hondt, yaitu membagi perolehan suara setiap partai politik dengan bilangan pembagi 1, 3, 5, 7, dst. Hasilnya baginya dirangking, dan angka tertinggi secara berturut-

12 Rumah Pemilu, "Formula Pemilu", http://www.rumahpemilu.org/index.php/read/16/Formula-Pemilu (diakses 1 Juni 2013).

13 Ibid. 
turut mendapatkan kursi pertama, kursi kedua, kursi ketiga dst, sesuai dengan jumlah kursi yang tersedia. $^{14}$

Penyederhanakan partai politik tidak hanya dilakukan melalui pengaturan tentang ambang batas perolehan suara atau keterwakilan dalam parlemen, namun juga dapat dilakukan dengan menerapkan persyaratan yang memadai untuk menjadi partai politik peserta pemilihan umum. Persyaratan yang mudah akan mendorong masyarakat untuk membuat partai politik dan tidak hanya menjadikan partai politik sebagai alat untuk memeprjuangkan kepentingan politiknya, namun dalam tataran praktek sering hanya dijadikan untuk memperjuangkan kepentingan pragmatisnya.

Apabila dilihat dari jumlah partai politik maka pemilihan umum tahun 1955, 1999 dan 2004 merupakan pemilhan umum dengan peserta yang cukup banyak. Banyaknya jumlah peserta pemilihan umum ini lebih dikarenakan terlalu mudahnya persyaratan untuk membuat partai politik dan ikut sebagai peserta pemilihan umum dan sedikitnya partai politik peserta pemilihan umum 1977 sampai 1997 lebih dikarenakan rezim otoriter saat itu, sementara pemilihan umum tahun 2014 lebih dikarenakan ketatnya persyaratan partai politik sebagai peserta pemilihan umum.

Pemberian syarat yang berat ini sesungguhnya cukup efektif untuk membatasi jumlah partai politik tanpa harus ikut dalam pemilihan umum terlebih dahulu dengan demikian energi untuk menyaring jumlah partai yang akan ada di dalam parlemen juga tidak sebesar pada penerapan electoral threshold maupun parliamentary threshold.

\section{Putusan Mahkamah Konstitusi tentang ambang batas perolehan suara}

Amar putusan Mahkamah Konstitusi tentang permohonan uji materi atas Undang-Undang Nomor 8 Tahun 2012 tentang Pemilihan Umum Anggota Dewan Perwakilan Rakyat, Dewan Perwakilan Daerah, dan Dewan Perwakilan Rakyat Daerah, antara lain menyatakan :

a. Pasal 8 ayat (1) dan Penjelasan Pasal 8 ayat (1) Undang-Undang Nomor 8 Tahun 2012 tentang Pemilihan Umum Anggota Dewan Perwakilan Rakyat, Dewan Perwakilan Daerah, dan Dewan Perwakilan Rakyat Daerah LLembaran Negara Republik Indonesia Tahun 2012 Nomor 117 Tambahan Lembaran Negara Repulik Indonesia Nomor 5316) bertentangan dengan UUD 1945;

b. Pasal 8 ayat (2) Undang-Undang Nomor 8 Tahun 2012 tentang Pemilihan Umum Anggota Dewan Perwakilan Rakyat, Dewan Perwakilan Daerah, dan Dewan Perwakilan Rakyat Daerah (Lembaran Negara Republik Indonesia Tahun 2012 Nomor 117 Tambahan Lembaran Negara Repulik Indonesia Nomor 5316) sepanjang frasa "yang tidak memenuhi ambang batas perolehan suara pada Pemilu sebelumnya atau partai politik baru" dan Penjelasan Pasal 8 ayat (2) Undang-Undang Nomor 8 Tahun 2012 tentang Pemilihan Umum Anggota Dewan Perwakilan Rakyat, Dewan Perwakilan Daerah, dan Dewan Perwakilan Rakyat Daerah (Lembaran Negara Republik Indonesia Tahun 2012 Nomor 117 Tambahan Lembaran Negara Repulik Indonesia Nomor 5316) sepanjang frasa "yang dimaksud dengan "partai politik

14 Ibid. 
baru" adalah partai politik yang belum pernah mengikuti Pemilu" bertentangan dengan UUD 1945;

c. Pasal 17 ayat (1) dan Penjelasan Pasal 17 ayat (1) Undang-Undang Nomor 8 Tahun 2012 tentang Pemilihan Umum Anggota Dewan Perwakilan Rakyat, 102 Dewan Perwakilan Daerah, dan Dewan Perwakilan Rakyat Daerah (Lembaran Negara Republik Indonesia Tahun 2012 Nomor 117 Tambahan Lembaran Negara Repulik Indonesia Nomor 5316) bertentangan dengan UUD 1945;

d. Pasal 208 Undang-Undang Nomor 8 Tahun 2012 tentang Pemilihan Umum Anggota Dewan Perwakilan Rakyat, Dewan Perwakilan Daerah, dan Dewan Perwakilan Rakyat Daerah (Lembaran Negara Republik Indonesia Tahun 2012 Nomor 117 Tambahan Lembaran Negara Repulik Indonesia Nomor 5316) sepanjang frasa "DPRD provinsi, dan DPRD kabupaten/kota" bertentangan dengan UUD 1945;

e. Pasal 209 ayat (1) dan ayat (2) UndangUndang Nomor 8 Tahun 2012 tentang Pemilihan Umum Anggota Dewan Perwakilan Rakyat, Dewan Perwakilan Daerah, dan Dewan Perwakilan Rakyat Daerah (Lembaran Negara Republik Indonesia Tahun 2012 Nomor 117 Tambahan Lembaran Negara Repulik Indonesia Nomor 5316) sepanjang frasa "DPRD provinsi, dan DPRD kabupaten/ kota" bertentangan dengan UUD 1945;

f. Pasal 8 ayat (1) dan Penjelasan Pasal 8 ayat (1) Undang-Undang Nomor 8 Tahun 2012 tentang Pemilihan Umum Anggota Dewan Perwakilan Rakyat, Dewan Perwakilan Daerah, dan Dewan Perwakilan Rakyat Daerah (Lembaran Negara Republik Indonesia Tahun 2012 Nomor 117 Tambahan Lembaran Negara Repulik Indonesia Nomor
5316) tidak mempunyai kekuatan hukum mengikat;

g. Pasal 8 ayat (2) Undang-Undang Nomor 8 Tahun 2012 tentang Pemilihan Umum Anggota Dewan Perwakilan Rakyat, Dewan Perwakilan Daerah, dan Dewan Perwakilan Rakyat Daerah (Lembaran Negara Republik Indonesia Tahun 2012 Nomor 117 Tambahan Lembaran Negara Repulik Indonesia Nomor 5316) sepanjang frasa "yang tidak memenuhi ambang batas perolehan suara pada Pemilu sebelumnya atau partai politik baru" dan Penjelasan Pasal 8 ayat (2) Undang-Undang Nomor 8 Tahun 2012 tentang Pemilihan Umum Anggota Dewan Perwakilan Rakyat, Dewan Perwakilan Daerah, dan Dewan Perwakilan Rakyat Daerah (Lembaran Negara Republik Indonesia Tahun 2012 Nomor 117 Tambahan Lembaran Negara Repulik Indonesia Nomor 5316) sepanjang frasa 103 "yang dimaksud dengan "partai politik baru" adalah partai politik yang belum pernah mengikuti Pemilu" tidak mempunyai kekuatan hukum mengikat;

h. Pasal 17 ayat (1) serta Penjelasan Pasal 17 ayat (1) Undang-Undang Nomor 8 Tahun 2012 tentang Pemilihan Umum Anggota Dewan Perwakilan Rakyat, Dewan Perwakilan Daerah, dan Dewan Perwakilan Rakyat Daerah (Lembaran Negara Republik Indonesia Tahun 2012 Nomor 117 Tambahan Lembaran Negara Repulik Indonesia Nomor 5316) tidak mempunyai kekuatan hukum mengikat;

i. Pasal 208 Undang-Undang Nomor 8 Tahun 2012 tentang Pemilihan Umum Anggota Dewan Perwakilan Rakyat, Dewan Perwakilan Daerah, dan Dewan Perwakilan Rakyat Daerah (Lembaran Negara Republik Indonesia Tahun 2012 Nomor 117 Tambahan 
Lembaran Negara Repulik Indonesia Nomor 5316) sepanjang frasa "DPRD provinsi, dan DPRD kabupaten/kota" tidak mempunyai kekuatan hukum mengikat;

j. Pasal 209 ayat (1) dan ayat (2) UndangUndang Nomor 8 Tahun 2012 tentang Pemilihan Umum Anggota Dewan Perwakilan Rakyat, Dewan Perwakilan Daerah, dan Dewan Perwakilan Rakyat Daerah (Lembaran Negara Republik Indonesia Tahun 2012 Nomor 117 Tambahan Lembaran Negara Repulik Indonesia Nomor 5316) sepanjang frasa "DPRD provinsi, dan DPRD kabupaten/ kota" tidak mempunyai kekuatan hukum mengikat;

Putusan tentang pembatalan Pasal 8 ayat (1) dan revisi pada ayat (2) ini memberi konsekuensi bahwa partai politik yang pada saat pemilihan umum tahun 2009 memenuhi persyaratan ambang batas dapat langsung menjadi peserta pemilihan umum tanpa harus memenuhi persyaratan sebagaimana ditentukan di dalam Undang-Undang Nomor 8 tahun 2012, harus dibatalkan sehingga seluruh partai politik baik yang pernah mengikuti pemilihan umum atau yang sama sekali baru harus memenuhi pensyaratan.

Pembatalan atas Pasal 208 Undang-Undang Nomor 8 tahun 2012 ini mengakibatkan penetapan ambang batas peroleh suara hanya diberlakukan pada suara secara nasional. Dengan demikian, sebuah partai politik yang akan memperoleh kursi di DPR pusat hanya partai politik yang memperoleh suara nasional (suara untuk kursi DPR pusat) di atas ambang batas.

Untuk Pasal 209 yang dinyatakan bertentangan dengan Undang-Undang Dasar 1945, memiliki akibat hukum yang relatif sama dengan pembatalan Pasal 208 yaitu partai politik peserta pemilihan umum yang tidak lolos dalam ambang batas perolehan suara tidak secara otomatis tidak disertakan dalam penghitungan perolehan kursi di seluruh jenjang. Partai politik tersebut hanya tidak diikutkan dalam penghitungan perolehan kursi di tingkat nasional. Dengan demkian partai politik peserta pemilihan umum yang tidak lolos dalam ambang batas masih diikutsertakan dalam penghitungan perolehan kursi di tingkat provinsi dan kabupaten atau kota.

Ambang batas perolehan suara sebagaimana diatur dalam Pasal 208 sekurang-kurangnya adalah tiga koma lima persen dari jumlah suara nasional. Ambang batas ini meskipun mengambil patokan suara nasional namun berlaku untuk tingkat provinsi dan kabupaten dan kota sehingga berapapun perolehan suara di tingkat provinsi dan kabupaten dan kota akan sangat tergantung dari ambang batas perolehan suara di tingkat nasional.

Sesuai dengan teori bahwa semakin besar angka ambang batas maka akan semakin besar indeks disproporsionalitas pemilihan umum dengan kata lain besaran angka ambang batas akan berbanding lurus dengan hilangnya suara. Ketentuan Pasal 208 dan 209 UndangUndang pemilu 2012 yang menerapkan angka ambang batas di seluruh jenjang akan semakin memperbesar disproporsionalitas dalam pemilihan umum.

Mahkamah Konstitusi tidak menyatakan bahwa penentuan ambang batas itu bertentangan dengan Undang-Undang Dasar 1945. Hanya saja ketika pemberlakuan atas ambang batas suara nasional itu juga diterapkan di tingkat daerah propvinsi dan kabupaten kota, maka suara yang hilang di daerah dikarenakan faktor nasional bukan karena faktor daerah. 
Dalam Putusan Mahkamah Konstitusi Nomor 52/PUU-X/2012 poin 3.25.1 menyatakan "menurut Mahkamah, pemberlakuan ambang batas secara nasional yang mempunyai akibat hukum pada hilangnya kursi-kursi partai politik yang tidak memiliki kursi di DPR namun partai politik bersangkutan memenuhi ketentuan bilangan pembagi pemilih di daerah dan menjadikan kursi-kursi tersebut dimiliki partai politik lain yang sebenarnya tidak memenuhi bilangan pembagi pemilih namun memiliki kursi di DPR, justru bertentangan dengan kedaulatan rakyat, hak politik, dan rasionalitas, sehingga bertentangan pula dengan tujuan pemilihan umum itu sendiri yaitu untuk memilih wakil rakyat mulai dari tingkat pusat hingga daerah.

Kedua diterapkan secara keseluruhan baik di tingkat pusat maupun daerah, hal ini disampaikan pemerintah dalam penjelasan pemerintah nomor 10. Putusan MK nomor 52/ PUU-X/2012 menyatakan "Kebijakan terkait pemberlakuan PT secara nasional diharapkan dapat menciptakan sinergitas program yang dijalankan pemerintah pusat dan daerah. Fakta yang terjadi sebelumnya sering kali program yang dicanangkan pemerintah pusat tidak sejalan dengan kebijakan yang ada di daerah. Hal ini disebabkan masing-masing keterwakilan partai politik di DPR dan DPRD berbeda latar belakangnya dikarenakan dalam Pemilu Tahun 2009, partai politik yang terwakili di DPR belum tentu mempunyai keterwakilan di DPRD, begitu juga sebaliknya. Hal ini sangat mempengaruhi sinergitas program pembangunan di pusat dan daerah, sehingga penyelenggaraan Pemerintah kurang efektif.

Kata-kata, "justru bertentangan dengan kedaulatan rakyat, hak politik, dan rasionalitas, sehingga bertentangan pula dengan tujuan pemilihan umum itu sendiri yaitu untuk memilih wakil rakyat mulai dari tingkat pusat hingga daerah" ini memberi makna bahwa penerapan ambang batas peroleh suara sampai di tingkat daerah dinilai bertentangan Undang-Undang Dasar 1945.

Mahkamah Konstitusi tidak mempersoalkan apakah penentuan angka ambang batas perolehan suara itu bertentangan atau tidak bertentangan dengan konstitusi, namun lebih diarahkan pada pertanyaan apakah penerapan ambang batas tersebut bertentangan atau tidak bertentangan dengan kedaulatan rakyat, hak politik, dan rasionalitas, dan tujuan pemilihan umum itu sendiri yaitu untuk memilih wakil rakyat mulai dari tingkat pusat hingga daerah.

Persoalan hilangnya suara di dalam pemilihan umum sesungguhnya, ada atau tidak ada ambang batas, hampir dipastikan akan ada suara yang hilang. Sebagai ilustrasi ketika sebuah pemilihan umum tidak ada ambang batas perolehan suara maka bagi partai politik yang tidak memenuhi syarat dalam perolehan kursi atau suara yang diperolehnya di bawah bilangan pembagi maka secara otomatis suara itu akan hilang. Hilangnya suara tersebut bukan karena ada ketentuan tentang ambang batas namun dihilangkan oleh batas bilangan pembagi.

Logika terdapat hak rakyat atau kedaulatan rakyat yang hilang oleh karena ketetapan ambang batas sesungguhnya tidak tepat. Dalam sistem pemilihan umum di Indonesia terutama dua pemilihan umum terakhir seluruh rakyat diberi kesempatan yang sama dalam menggunakan hak pilihnya. Persoalan apakah rakyat menggunakan hak pilihnya atau kedaulatannya atau tidak (golongan putih) maka itu bukan lagi kewajiban undangundang pemilihan umum untuk memastikan rakyat menggunakan kedaulatannya. Logika ini akan sama dengan sesorang yang sudah 
menggunakan hak pilihnya namun oleh karena aspirasi rakyat yang lain lebih besar maka suara kecil ini harus tersingkir oleh suara yang besar dengan kata lain kehendak mayoritas dapat mengalahkan atau menghilangkan pendapat minoritas walaupun minoritas tetap dijamin haknya.

Dengan demikian tidak masuk akal kalau sebuah kekalahan dalam pemilihan umum dan mengakibatkan suara mereka tidak tersalur atau dalam bahasa lain suaranya hilang karena tidak memenuhi syarat maka disalahkan persyaratan tersebut.

Ada beberapa penyebab sebuah partai politik peserta pemilihan umum itu mengalami kehilangan suara yaitu:

a. suara yang diperoleh tidak memenuhi syarat ambang batas peroleha suara. Hal ini telah diatur pada Pasal 208 yang menetapkan ambang batas perolehan suara 3,5\%;

b. cara mengkonversi suara ke kursi baik di tingkat nasional maupun daerah. Pasal 212 Undang-Undang nomor 8 tahun 2012 mengatur konversi tersebut dengan metode kuota murni. Penghitungan ini memberi kesempatan bagi partai politik peraih sisa suara terbanyak untuk memperoleh kursi namun tetap saja akan terdapat sisa suara yang hilang. Begitu juga dengan metode divisor Webster atau metode d'Hondt akan selalu mengorbankan sebagian sisa suara tersebut.

Penulis beranggapan bahwa hilangnya suara sisa tersebut merupakan konsekuensi logis dari sebuah kompetisi dan akan terjadi secara alamiah sehingga tidak perlu untuk dikaitkan dengan persoalan pengabaian terhadap kedaulatan rakyat sebagaimana diatur di dalam Pasal 1 ayat (2) dan Pasal 22E ayat (1) UUD 1945.
Undang-Undang pemilu tahun 2012 telah memberikan seluruh hak rakyat dalam menyalurkan aspirasinya dengan atau tanpa ambang batas dan ketika seluruh aspirasi sudah tersalur maka yang ada adalah apakah aspirasi itu merupakan aspirasi sebagian besar rakyat Indonesia? Ketika aspirasi itu merupakan aspirasi masyoritas maka itulah yang dinamakan aspirasi atau kedaulatan rakyat dan sebaliknya.

\section{Penerapan ambang batas perolehan suara}

Penetapan ambang batas perolehan suara pada dasarnya dilakukan dengan dua macam cara yaitu secara natural atau efektif (legal threshold) dan ambang batas tersembunyi (hidden threshold).

Ambang batas yang dikategorikan sebagai ambang batas natural dalam Undang-Undang pemilu tahun 2012 terdapat pada Pasal 208 yang menyatakan bahwa Partai Politik Peserta Pemilu harus memenuhi ambang batas perolehan suara sekurang-kurangnya 3,5\% (tiga koma lima persen) dari jumlah suara sah secara nasional untuk diikutkan dalam penentuan perolehan kursi anggota DPR, DPRD provinsi,dan DPRD kabupaten/kota. Pasal ini memberi pengertian bahwa partai politik peserta pemilihan umum yang tidak memenuhi 3.5\% jumlah suara sah secara nasional (suara untuk DPR RI) secara otomatis tidak diikutkan dalam penentuan perolehan kursi di seluruh jenjang. Dengan demikian seluruh suara baik di tingkat pusat maupun daerah akan hilang.

Ketentuan ini memungkinkan sebuah partai yang mendapat suara secara mayoritas di daerah tidak mendapat kursi oleh karena partainya tidak lolos ambang batas secara nasional, sebaliknya sebuah partai yang memperoleh suara minimal di sebuah daerah akan mendapatkan kursi 
hanya karena perolehan suara secara nasional memenuhi ambang batas.

Konsekuensi logis dari ketentuan ini adalah partai yang dapat bertahan untuk dapat duduk di parlemen adalah partai yang memiliki jaringan luas dan sumber daya manusia yang memadai baik dari aspek jumlah maupun kualitas, sementara partai kecil meskipun punya basis massa di beberapa tempat tertentu akan tidak akan mendapatkan bagian kursi.

Ketentuan lebih lanjut terhadap ambang batas ini terdapat pada Pasal 209 ayat (1) yang secara lengkap menyatakan bahwa partai Politik Peserta Pemilu yang tidak memenuhi ambang batas perolehan suara sebagaimana dimaksud dalam Pasal 208, tidak disertakan pada penghitungan perolehan kursi DPR , DPRD provinsi, dan DPRD kabupaten/kota di setiap daerah pemilihan.

Ketentuan ambang batas ini akan sangat menguntungkan partai besar. Semakin besar angka ambang batas dalam pemilihan umum maka akan semakin menguntungkan partai besar. Penentuan ambang batas sebesar 3,5 $\%$ ini walaupun membatasi namun batasan tersebut tidak terlalu besar sehingga masih memungkinkan partai menengah untuk dapat memperoleh kursi. Namun bagi partai kecil tidak akan mendapat kesempatan untuk duduk di parlemen baik di tingkat pusat maupun daerah.

Ketentuan ini memang dapat mengurangi partai yang akan duduk di parlemen secara efektif sehingga hanya partai besar dan mungkin juga partai menengah yang akan berperan dalam mengelola pemerintahan baik dalam yang akan mengelola eksekutif maupun yang legislative sebagai partai oposisi. ${ }^{15}$ Sedikitnya partai yang duduk dalam parlemen juga akan mengurangi friksi yang ada dalam pengelolaan eksekutif maupun di parlemen.

Penentuan ambang batas efektif ini secara otomatis memberi peluang yang besar untuk mengurangi partai yang akan duduk di parlemen. Pada saat hasil pemungutan suara terdapat partai politik yang tidak lulus ambang batas tersebut maka secara otomatis suara yang diperoleh partai tersebut menjadi hilang karena tidak ikut dihitung.

Pasal 209 ayat (2) Undang-Undang Nomor 8 Tahun 2012 menyatakan menyatakan suara untuk penghitungan perolehan kursi DPR, DPRD provinsi, dan DPRD kabupaten/kota di suatu daerah pemilihan ialah jumlah suara sah seluruh Partai Politik Peserta Pemilu dikurangi jumlah suara sah Partai Politik Peserta Pemilu yang tidak memenuhi ambang batas perolehan suara sebagaimana dimaksud dalam Pasal 208.

Selanjutnya pada ayat (3) menyatakan bahwa dari hasil penghitungan suara sah yang diperoleh Partai Politik Peserta Pemilu sebagaimana dimaksud pada ayat (2) di suatu daerah pemilihan ditetapkan angka BPP DPR , BPP DPRD provinsi, dan BPP DPRD kabupaten/ kota dengan cara membagi jumlah suara sah

15 Istilah oposisi ini sesungguhnya tidak dikenal di dalam system presidensiil, namun praktek politik dan ketatanegaraan Indonesia mendorong keadaan partai atau di parlemen menjadi dua kutub (bipolar) yaitu partai yang mendukung presiden terpilih baik partai itu berasal dari presiden terpilih atau partai yang ikut mendukung presiden terpilih dengan berbagai kompensasi. Sementara bagi partai yang tidak mendukung presiden terplih akan memposisikan sebagai partai oposisi walaupun tidak sepenuhnya memiliki kekuatan untuk untuk mengganti kepala pemerintahan sebagaimana sistem parlementer. Dalam menempatkan sebagai oposisi pun tidak selalu berada pada ststusnya sebagai oposisi. Akan sangat mungkin partai itu berubah haluan menjadi pendukung pemerintah sehingga kalaupun diistilahkan sebagai oposisi akan lebih tepat disebut sebagai partai quasi oposisi. 
Partai Politik Peserta Pemilu sebagaimana dimaksud pada ayat (2) dengan jumlah kursi di satu daerah pemilihan.

Ketentuan ini memberi kemungkinan bahwa harga kursi disetiap daerah pemilihan akan sangat bervariasi. Hal ini selain karena jumlah penduduk yang berhak memilih, jumlah penduduk yang tidak menggunakan haknya (golongan putih (golput)), juga oleh karena jumlah suara yang hilang akibat partai politik tertentu tidak lolos ambang batas.

Bagi daerah pemilihan yang jumlah penduduk yang mempunyai hak pilih sedikit serta jumlah golongan putihnya besar ditambah banyak suara hilang akibat partai politik tidak lolos ambang batas maka nilai sebuah kursi di parlemen menjadi sangat murah.
Sebaliknya pada daerah pemilihan yang jumlah penduduk yang memiliki hak pilihnya padat atau tinggi sedang jumlah golongan putih rendah serta sedikit partai politik yang tidak lolos ambang batas maka nilai kursi parlemen menjadi sangat tinggi. Keadaan ini bervariasi tergantung dari keadaan variabel yang ada pada daerah pemilihan tersebut.

Pada saat bilangan pembagi (jumlah suara untuk satu kursi) sudah dapat ditentukan maka kursi dapat ditetapkan. Undang-Undang ini menggunakan metode untuk menetapkan kursi dengan metode quota murni. Metode kuota murni adalah penentuan kursi dengan membagi habis suara di daerah pemilihan. Sebagai ilustrasi disampaikan simulasi penetapan kursi di daerah pemilihan Nusa Tenggara Barat pada pemilihan umum tahun 2009.

Tabel 1: simulasi penetapan kursi di NTB pada Pemilu 2009

\begin{tabular}{|c|c|c|c|c|c|c|c|c|}
\hline \multirow[b]{2}{*}{ Suara sah } & \multicolumn{8}{|c|}{ Perolehan Suara } \\
\hline & HANURA & GERINDRA & PKS & PAN & PPP & GOLKAR & PDIP & DEMOKRAT \\
\hline 1.962 .300 & 92.756 & 74.613 & 157.591 & 94.355 & 102.370 & 291.452 & 92.052 & 352.801 \\
\hline & $4.73 \%$ & $3.80 \%$ & $8.03 \%$ & $4.81 \%$ & $5.22 \%$ & $14.85 \%$ & $4.69 \%$ & $17.98 \%$ \\
\hline Masuk ambang batas & $64.11 \%$ & & & & & & & \\
\hline Terhapus ambang batas & $35.89 \%$ & & & & & & & \\
\hline Suara terhapus & 704.310 .00 & & & & & & & \\
\hline $\begin{array}{l}\text { Suara sah setelah dip } \\
\text { ambang batas }\end{array}$ & 1.257 .990 .00 & & & & & & & \\
\hline Bilangan pembagi & 125.799 & & & & & & & \\
\hline Putaran 1 & kursi & suara & sisa & & & & & \\
\hline Democrat & 2 & 251.598 & 101.103 & & & & & \\
\hline Golkar & 2 & 251.598 & 39.854 & & & & & \\
\hline PKS & 1 & 125.799 & 31.792 & & & & & \\
\hline & $>$ & & & & & & & \\
\hline Putaran II (warna n & & & & & & & & \\
\hline Demokrat & 1 & Kursi ke 6 & & & & & & \\
\hline PPP & 1 & Kursi ke 7 & & & & & & \\
\hline PAN & 1 & Kursi ke 8 & & & & & & \\
\hline HANURA & 1 & Kursi ke 9 & & & & & & \\
\hline PDIP & 1 & Kursi ke 10 & & & & & & \\
\hline Partai & HANURA & GERINDRA & PKS & PAN & PPP & GOLKAR & PDIP & DEMOKRAT \\
\hline Kursi & 1 & 1 & 1 & 1 & 1 & 2 & 1 & 3 \\
\hline
\end{tabular}

Sumber: Harja Saputra, Apa dan Bagaimana Metode Perhitungan Kursi Kuota Murni, Voice of humanism http://www. harjasaputra.com/opini/polhukam/apa-dan-bagaimana-metode-perhitungan- kursi- kuota-murni.html (diakses 3 Juli 2013). 
Metode kuota murni memang cenderung menguntungkan partai menengah- kecil dan merugikan partai besar. Partai seperti PAN,PPP,PKB, Gerindra dan Hanura sejak awal mengusulkan metode kuota murni karena partai mereka akan diuntungkan dengan metode ini. Metode kuota murni berbanding terbalik dengan metode d'Hondt yang justru menguntungkan partai besar dan merugikan partai menengah-kecil.

Membandingkan kedua metode itu, metode divisor varian Webster dinilai paling proposional dan lebih adil, karena itu PDIP, Golkar dan PKS mengusulkan metode Webster. Metode ini tidak mengandung bias terhadap partai besar maupun kecil. ${ }^{16}$

Melihat politik hukum pemilihan hukum Undang-Undang pemilihan umum tahun 2012 ini sangat terlihat bahwa sesungguhnya, meskipun partai politik sepakat tentang penyederhanaan partai politik untuk efisiensi dan efektifitas pemerintahan namun tidak pernah terlepas dari kepentingan eksistensi seluruh partai politik itu, terutama partai yang duduk di kursi parlemen.

Pandangan Fraksi atas cara penghitungan ini dapat dilihat dalam tabel sebagai berikut:

Tabel 2. Pandangan Fraksi tentang metode penghitungan/konversi suara

\begin{tabular}{|c|l|l|}
\hline No & \multicolumn{1}{|c|}{ Partai Politik } & \multicolumn{1}{c|}{ Usulan } \\
\hline 1 & Partai Golongan Karya & Divisor Webster \\
\hline 2 & Partai Demokrat & Kuota murni \\
\hline 3 & Partai demokrasi Indonesia Perjuangan & Divisor Webster \\
\hline 4 & Partai Keadilan Sejahtera & Divisor Webster \\
\hline 5 & Partai Amanat Nasional & Kuota murni \\
\hline 6 & Partai Persastuan Pembangunan & Kuota murni \\
\hline 7 & Partai Kebangkitan Bangsa & Kuota murni \\
\hline 8 & Partai Gerakan Indonesia Raya & Kuota murni \\
\hline 9 & Partai Hati Nurani Rakyat & Kuota murni \\
\hline
\end{tabular}

Sumber: Harun Husein (dkk), Politik Hokum Sistem Pemilu:Potret Keterbukaan dan paratisipasi public dalam penyusunan Undang-Undang Nomor 8 tahun 2012 tentang pemilihan umum anggota DPR, DPD dan DPRD (Perludem, Jakarta, 2013), hlm 147.
Jika dilihat dari pemilihan umum tahun 2009 yang menerapkan ambang batas $2.5 \%$ dan pada Undang-Undang Nomor 8 Tahun 2012 ambang batas dinaikkan menjadi 3,5\% sesungguhnya para pembuat undang-undang sedang berusaha untuk lebih menyederhanakan partai politik yang akan berpartisipasi dalam mengelola pemerintahan.

Peningkatan ambang batas yang tinggi memang dimaksudkan sebagai upaya untuk menyederhanakan sistem kepartaian, tetapi di lain pihak, peningkatan ambang batas yang tinggi dan kurang wajar itu juga akan menambah jumlah suara terbuang. Padahal penambahan jumlah suara terbuang berakibat pada meningkatnya disproporsionalitas hasil Pemilu dan hal ini yang seharusnya dihindari dalam sistem Pemilu proporsional. Untuk mengetahui sejauh mana pengaruh penerapan ambang batas perwakilan terhadap bekerjanya sistem Pemilu proporsional, perlu dilakukan simulasi penghitungan besaran ambang batas yang berpengaruh terhadap suara terbuang sehingga meningkatkan disproporsionalitas. Dalam perspektif ini, dapat dikemukakan data KPU yang menggambarkan bahwa pada Pemilu 1999 yang tidak menerapkan ambang batas, terdapat $3.755 .383(3,55 \%)$ suara terbuang. Jika ambang batas diterapkan, jumlah suara terbuang akan bertambah. Misalnya dengan besaran ambang batas 2,5\%, yang diterapkan pada Pemilu 2009, maka jumlah suara terbuang melonjak lima kali lipat menjadi 14.195.221 (13,41\%). Hal ini berarti ambang batas mempunyai pengaruh positif terhadap peningkatan disproporsionalitas hasil Pemilu dan secara umum dapat digambarkan sebagai

16 Harun Husein, Op.Cit. hlm. 148. 
berikut,pertama, Pemilu 2004 menghasilkan $5.223 .845(4,60 \%)$ suara terbuang. Jumlah suara terbuang bertambah menjadi 19.662.644 (17,33\%) jika ambang batas $2,5 \%$ diberlakukan. Jumlah suara terbuang melonjak 5 kali lipat menjadi lebih dari 22.633 .131 (19,95\%) jika ambang batas ditingkatkan menjadi 3\% yang kedua, dengan ambang batas 2,5\%, Pemilu 2009 menghasilkan 19.047 .481 (18,13\%) suara terbuang. Sehingga secara teoretis dan dengan penalaran sederhana, dengan peningkatan ambang batas menjadi 3,5\%, jumlah suara terbuang itu akan semakin bertambah. ${ }^{17}$

Dengan demikian perlu pula untuk dipikirkan bagaimana membuat system dengan partai sederhana namun tidak mengurangi kualitas demokrasi khususnya dalam menjaga suara dalam pemilu agar tidak sia-sia dan memenuhi rasa keadilan. Kalau kemudian mengkaji Pasal 208 dan Pasal 209, maka penulis berpendapat bahwa penetapan angka ambang batas tidak bertentangan dengan Undang-Undang Dasar hanya saja penerapannya harus berjenjang.

Penerapan yang berjenjang itu artinya alat ukur terhadap ambang batas itu juga sesuai dengan jenjang masing-masing oleh karena itu penulis setuju dengan putusan Mahkamah Konstitusi bahwa ambang batas perolehan suara hanya untuk nasional karena memang alat ukur ambang batas itu adalah suara nasional. Penerapan ambang batas secara nasional ke perwakilan di tingkat daerah tentang saja tidak sesuai dan banyak menimbulkan deviasi.

Putusan Mahkamah konstitusi dengan tidak menerapkan ambang batas di tingkat daerah sesungguhnya memberikan pembedaan perlakuan antara perwakilan pusat dan daerah. Meskipun di daerah memiliki keragaman yang tinggi bukan berarti kemudian tidak mungkin ditetapkan ambang batas perolehan suara.

Dengan demikian sesungguhnya penetapan angka ambang batas natural itu tidak bertentangan dengan Undang-Undang Dasar 1945 hanya saja penerapan yang tidak tepat di tataran nasional maupun daerah membuat ambang batas ini menjadi banyak mengalami deviasi.

Sedang penentuan jumlah kursi di setiap jenjang ini secara tidak langsung juga akan menyeleksi partai politik yang akan masuk ke DPR, DPRD provinsi dan DPRD Kabupaten atau Kota karena dengan kuota yang terbatas tersebut maka tidak mungkin semua partai akan memperoleh kursi.

Secara umum ketentuan ini memang berlaku di negara-negara di seluruh dunia dan dianggap sebagai sebuah ketentuan yang wajar meskipun pada hakekatnya adalah pembatasan. Persoalan jumlah pun tidak pernah dipersoalkan apakah jumlah tersebut dirasa bertentangan dengan atau tidak dengan konstitusi.

Konsep demokrasi langsung memang tidak mengenal pembatasan karena tidak ada perwakilan dalam forum demokrasi tersebut setiap rakyat dapat secara langsung menjadi anggota parlemen sehingga keputusankeputusan besar selalu melibatkan parlemen yang beranggotakan seluruh rakyat. Maka menjadi wajar kalau demkroasi langsung tidak pernah ada pembatasan.

Penetapan rentang jumlah kursi DPR, DPRD Provinsi dan DPRD Kabupaten dan

17 Mas Isharyanto, "Ambang Batas Parlemen Untuk Penyederhanaan Partai", http://hukum.kompasiana.com /2013/05/27/ambang- batas-parlemen-untuk-penyederhanaan- partai-563798. html (diakses 4 Juni 2013). 
kota sebagaimana diatur di dalam UndangUndang Nomor 8 Tahun 2012 merupakan rasio proporsional antara jumlah penduduk dengan jumlah kursi. Semakin besar jumlah penduduk di satu wilayah maka akan semakin besar pula kuota jumlah kursi yang tersedia.

Menurut penulis, ditetapkannya kuota kursi di setiap lembaga perwakilan tersebut tidak bertentangan dengan konstitusi karena pembatasan jumlah kursi merupakan keniscayaan dalam demokrasi tidak langsung. Banyaknya jumlah penduduk tidak memungkinkan demokrasi dijalan secara langsung sebagaimana negara kecil atau Negara Yunani zaman dahulu. Demokrasi perwakilan membutuhkan pembatasan sebagai representasi dari rakyat secara keseluruhan.

Bentuk ambang batas tersembunyi yang kedua adalah kuota jumlah kursi yang ada di daerah pemilihan. Di tingkat DPR pusat rentang jumlah kursi di tiap daerah pemilihan adalah ditentukan paling sedikit 3(tiga) kursi dan paling banyak 10 (sepuluh) kursi. Hal ini diatur pada Pasal 22 ayat (2). Sedangkan kuota kursi tiap daaerah pemilihan DPRD Provinsi dan Kabupaten atau kota adalah provinsi paling sedikit 3 (tiga) kursi dan paling banyak 12 (dua belas) kursi. Ketetapan ini diatur pada Pasal 24 ayat (2) dan Pasal 26 ayat (1) Undang-Undang Nomor 8 tahun 2012.

Sebagaimana Penetapan jumlah kursi di DPR dan DPRD, penetapan ambang batas ini tidak bertentangan dengan konstitusi dengan logika yang sama bahwa demokrasi tidak langsung memang diperlukan pembatasan. selain merupakan konsekuensi logis dari demokrasi tidak langsung. Selain itu, hal yang membuat ketentuan ini tidak bertentangan dengan UUD 1945 khususnya Pasal 22E adalah diberikanya hak dan kewajiban serta peluang secara sama kepada seluruh partai politik perserta pemilihan umum untuk mendapatkan suara dan kursi semaksimal mungkin sesuai dengan aturan main.

Pengaturan ambang batas perolehan suara nasional yang diterapkan di seluruh jenjang memang telah dikoreksi oleh Mahkamah Konstitusi dengan hanya memberlakukan jenjang di tingkat nasional saja. Putusan Mahkamah Konstitusi ini masih menyisakan persoalan di jenjang provinsi dan kabupatenKota karena di jenjang Kabupaten dan Kotamadya tidak diterapkan ambang batas.

Akibat tidak diterapkan ambang batas di tingkat daerah masalah yang muncul akibat tidak ada ambang batas perolehan suara yang terjadi di tingkat nasional justru akan bergeser ke daerah.

Bagaimanapun undang-undang tidak boleh hanya memperhatikan stabilitas social politik hanya pada tataran nasional saja dengan mengabaikan daerah. Instabilitas social politik di daerah yang merata juga akan sangat mempengaruhi stabilitas nasional oleh karena itu penyederhanaan partai dalam rangka untuk mendapatkan sistem politik dan demokrasi yang kuat dan stabil harus dilakukan di seluruh jenjang.

Penerapan ambang batas perolehan suara di setiap jenjang akan menghasilkan komposisi partai politik di di DPR dan DPRD yang bervariasi. Meskipun tidak terjadi kesamaan komposisi partai politik ditingkat nasional, provinsi maupun kabupaten dan kota sesungguhnya komposisi tersebut tidak membuat pemerintahan menjadi labil.

Penulis mengusulkan bahwa agar tercapai kehidupan politik dan ketatanegaraan yang sehat maka penerapan ambang batas serta alat ukurnya harus disesuaikan dengan jenjangnya. Ambang batas nasional harus diterapkan 
dengan alat ukur berupa perolehan suara secara nasional demikian juga ambang batas perolehan suara pada perwakilan di daerah harus diterapkan dengan alat ukur berupa perolehan suara di daerah sesuai dengan jenjangnya masing-masing.

\section{E. Penutup}

\section{Kesimpulan}

Pengaturan ambang batas perolehan suara pada Undang-Undang nomor 8 tahun 2012 tidak bertentangan dengan Undang-Undang Dasar 1945. Setelah putusan Mahkamah Konstitusi keluar maka penetapan ambang batas ini hanya diberlakukan pada perwakilan di tingkat nasional saja Sementara perwakilan di jenjang daerah tidak diberlakukan. hal ini berarti Mahkamah Konstitusi memberikan pengaturan yang berbeda tentang ambang batas perolehan suara antara perwakilan di tingkat nasional dengan yang ada di daerah. Padahal bukan tidak mungkin pengelolaan di tingkat daerah menjadi tidak efektif dan efisien yang disebabkan oleh terlalu majemuknya partai politik yang duduk di Dewan Perwakilan Rakyat Daerah. Ambang batas perolehan suara seharusnya diterapkan di setiap jenjang sehingga seleksi partai politik juga terjadi pada setiap jenjang.

\section{Saran}

Ambang batas perolehan suara memang harus diterapkan agar pengelolaan pemerintahan dapat dijalankan secara efektif dan efisien namun dalam penerapannya juga harus disesuaikan dengan jenjangnya agar tidak terjadi penyimpangan. Apabila pengaturan ambang batas ditingkat nasional berdasar perolehan suara nasional maka untuk menciptakan pengelolaan pemerintahan yang efektif dan efisien di tingkat daerah sebaiknya ketentuan ambang batas juga diterapkan di perwakilan tingkat provinsi dan kabupaten atau kota.

\section{DAFTAR PUSTAKA}

\section{Buku}

Gafar, Affan, Politik Indonesia Transisi Menuju Demokrasi (Yogyakarta: Pustaka Pelajar, 2000).

Didik, Supriyanto \& August Mellaz, Ambang batas perwakilan (Jakarta: Perludem, 2011).

Husein, Harun, et.al., Politik Hokum Sistem Pemilu:Potret Keterbukaan dan paratisipasi public dalam penyusunan Undang-Undang Nomor 8 tahun 2012 tentang pemilihan umum anggota DPR, DPD dan DPRD (Jakarta: Perludem, 2013).

\section{Makalah / Artikel / Prosiding / Hasil Penelitian}

Lili Romli, "Reformasi Partai Politik dan Sistem Kepartaian di Indonesia" Jurnal Politica, Volume 2 November (2011).

\section{Internet}

Harja Saputra, "Apa dan Bagaimana Metode Perhitungan Kursi Kuota Murni", http://www. harjasaputra.com/opini/polhukam/apa-danbagaimana-metode-perhitungan-kursi- kuotamurni.html, (diakses 3 Juli 2013).

Mas Isharyanto, "Ambang Batas Parlemen Untuk Penyederhanaan Partai", http://hukum. kompasiana.com/2013/05/27/ambangbatas-parlemen-untuk-penyederhanaanpartai-563798 html (diakes 4 Juli 2013).

Rumah Pemilu, "Formula Pemilu", http://www. rumahpemilu.org/index.php/read/16/ FormulaPemilu (diakses 1 juni 2013).

\section{Peraturan}

Undang-Undang Dasar 1945

Undang-Undang Nomor 8 tahun 2012 tentang Pemilihan Umum Anggota Dewan Perwakilan Rakyat,

\section{Putusan Pengadilan}

Putusan Mahkamah Konstitusi Nomor 52/PU$\mathrm{X} / 2012$ 